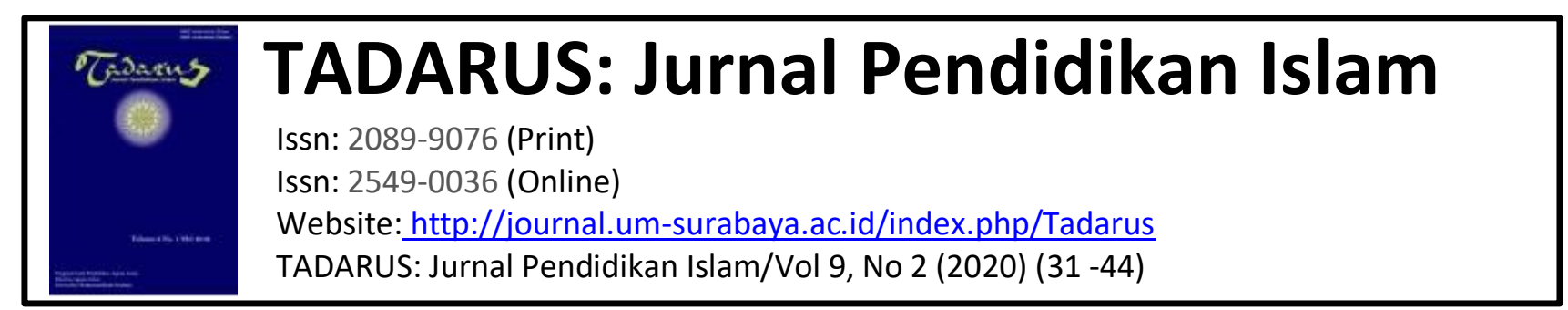

\title{
PENGARUH APLIKASI METODE DISCOVERY LEARNING DALAM MENINGKATKAN MOTIVASI BELAJAR SISWA DI MTs PONDOK PESANTREN SALMAN AL-FARISI KARANGANYAR SOLO
}

\author{
${ }^{1}$ Muhammad Hambal, ${ }^{2}$ Muhammad Fathul Khoiruddin \\ ${ }^{1}$ abu.hana.tsania@gmail.com, ${ }^{2}$ mfkh87@gmail.com
}

\begin{abstract}
Abstrak
Penelitian ini bertujuan untuk membahas bagaimanakah pelaksanaan metode Discovery Learning di MTs Pondok Pesantren Salman Al-Farisi Karanganyar Solo; dan adakah pengaruh metode Discovery Learning terhadap motivasi belajar siswa yang dilaksanakan di MTs Pondok Pesantren Ssalman Al-Farisi Karanganyar Solo. Adapun bentuk penelitian ini adalah penelitian kuantitatif yang menggunakan populasi, karena yang diteliti adalah semua siswa kelas VII di MTs Pondok Pesantren Salman Al-Farisi Karanganyar Solo. Dalam pengumpulan data, penulis menggunakan tehnik pengumpulan data berupa observasi, interview (wawancara), dokumentasi, dan angket. Untuk mengetahui pelaksanaan metode Discovery Learning dan motivasi belajar siswa penulis menggunakan rumus prosentase, sedangkan untuk mengetahui ada tidaknya pengaruh metode Discovery Learning terhadap motivasi belajar siswa penulis menggunakan rumus product moment (rxy). Hasil penelitian ini menunjukkan bahwa tidak ada pengaruh aplikasi metode Discovery Learning terhadap motivasi belajar siswa dengan skor 0.077. Jika dilihat pada tabel interpretasi nilai " $r$ " product moment berada pada rentang $0.00-0.20$ yang berarti antara variabel $\mathrm{x}$ dan varibel y terdapat korelasi yang sangat lemah atau sangat rendah (dianggap tidak ada korelasi di antara keduanya).
\end{abstract}

Kata kunci : Aplikasi, Discovery, Learning, Motivasi dan Belajar

\section{Pendahuluan}

Kualitas kehidupan bangsa sangat ditentukan oleh faktor pendidikan. Peran pendidikan sangat penting untuk menciptakan kehidupan yang cerdas, damai, terbuka, dan demokratis. Di samping itu, tuntutan terhadap kualitas pendidikan yang terus meningkat, kemajuan ilmu pengetahuan, dan teknologi untuk memenuhi kebutuhan masyarakat yang semakin berkembang menuntut dunia pendidikan nasional melakukan upaya pembaruan menuju pendidikan yang kompetitif dan inovatif, dengan melakukan pembaruan pendidikan. 
Dalam konteks pembaruan pendidikan, ada tiga isu yang perlu disoroti, yaitu pembaruan kurikulum, peningkatan kualitas pembelajaran, dan efektifitas metode pembelajaran. ${ }^{1}$ Metode pembelajaran mempunyai andil yang cukup besar dalam kegiatan belajar mengajar. Kemampuan yang diharapkan dapat dimiliki anak didik, ditentukan oleh kerelevansian penggunaan suatu metode yang sesuai dengan tujuan. ${ }^{2}$ Dengan demikian dalam pembaharuan pendidikan, harus dilakukan inovasi pembelajaran terhadap metode pembelajaran yang selama ini masih diterapkan.

Penggunaan metode pembelajaran yang teacher oriented dengan modus ekspository menjadikan siswa tidak aktif dan produktif, selayaknya mulai ditinggalkan. Penggunakan metode pembelajaran yang student oriented bermodus discovery yaitu siswa berperan dengan kadar keaktifan yang tinggi, dewasa ini mulai dikembangkan dengan mengaplikasikan metode Discovery Learning dalam pembelajaran di kelas.

Selain itu kualitas hasil belajar yang teacher oriented dan bermodus ekspository dewasa ini menjadikan siswa menguasai bahan pelajaran dengan dihafal dari pada menguasai keahlian tertentu. Sebagian besar dari siswa tidak mampu menghubungkan antara apa yang mereka pelajari dengan bagaimana pengetahuan tersebut akan digunakan/dimanfaatkan. Siswa memiliki kesulitan untuk memahami konsep akademik sebagaimana mereka biasa diajarkan, yaitu menggunakan sesuatu yang abstrak dan metode ceramah. Mereka sangat butuh untuk memahami konsepkonsep yang berhubungan dengan tempat kerja dan masyarakat pada umumnya di mana mereka akan hidup dan bekerja. ${ }^{3}$

Sedangkan dengan penerapan pembelajaran yang student oriented dan bermodus discovery menduduki peringkat yang tinggi dalam dunia pendidikan modern, ${ }^{4}$ dengan penggunaan metode Discovery Learning diharapkan dapat memperbaiki proses pembelajaran di kelas. Selain itu dasar pemikiran untuk memperbaiki proses pembelajaran dengan menggunakan metode discovery learning karena metode discovery learning memiliki kelebihan yang menekankan pentingnya keterlibatan siswa dalam proses belajar secara aktif. Kadar keaktifan yang tinggi

\footnotetext{
${ }^{1}$ Nurhadi, dkk, Pembelajaran Kontekstual dan Penerapannya dalam KBK, (Malang: Universitas Negeri Malang, 2004), 2

${ }^{2}$ Djamarah, Syaiful Bahri \& Aswan Zain, Strategi Belajar Mengajar, (Jakarta: Rineka Cipta, 2002), 3

${ }^{3}$ Nurhadi, dkk, Pembelajaran Kontekstual dan Penerapannya dalam KBK, (Malang: Universitas

Negeri Malang, 2004), 3

${ }^{4}$ Muhibbin Syah, Psikologi Pendidikan Dengan Pendekatan Baru, (Bandung: Remaja Rosda Karya, 2004), 243
} 
dalam proses belajar merupakan kegiatan yang paling pokok. Ini berarti bahwa berhasil tidaknya pencapaian tujuan pendidikan banyak bergantung kepada bagaimana proses belajar yang dialami oleh siswa sebagai anak didik. ${ }^{5}$

Pada kenyataannya proses pembelajaran pendidikan agama Islam yang tidak berfokus discovery, kerap kali bersifat seadanya, rutinitas, formalis, kering, dan kurang bermakna. Kualitas pembelajaran semacam itu akan menghasilkan mutu pendidikan agama yang rendah pula. ${ }^{6}$ Seharusnya hasil pembelajaran yang menjadi tujuan adalah pembelajaran itu dapat membawa siswa kepada perubahan tingkah laku (behavioral changes) baik aktual maupun potensial. Perubahan itu pada pokoknya adalah didapatkannya kecakapan baru dan perubahan itu terjadi karena usaha dengan sengaja. ${ }^{7}$ Sebagaimana pengertian belajar menurut Cronbach, yang mendefinisikan Learning is show by a change in behavior as result of experience. Sedangkan Harold Spears memberikan batasan tentang pengertian belajar, yaitu: Learning is to observe, to read, to imitate, to try something them selves, to listen, to follow direction.

Dari kedua definisi tersebut dapat disimpulkan bahwa belajar senantiasa merupakan perubahan tingkah laku atau penampilan dengan serangkaian kegiatan usaha sadar dengan melakukan beberapa aktivitas, yaitu: menulis mencatat memandang, membaca, mengingat, berfikir, latihan atau praktek, dan sebagainya. ${ }^{8}$ Sehingga membentuk kepribadian dan relevan dengan apa yang dipelajarinya.

Untuk memperbaiki keadaan tersebut dengan mengaplikasikan metode Discovery Learning menempatkan siswa pada kondisi pemahaman arti dan penggalian makna dengan belajar memahami konsep, arti, dan hubungan, melalui proses intuitif untuk akhirnya sampai kepada suatu kesimpulan. ${ }^{9}$ Disamping itu, dengan mengaplikasikan metode Discovery Learning bertujuan mengubah orientasi mempelajari Akidah Akhlak yang masih cenderung pada kemampuan membaca teks, belum mengarah pada pemahaman arti dan penggalian makna.

Sebagai lembaga pendidikan bercirikan Islam mempunyai peran yang strategis untuk membumikan nilai-nilai ajaran Islam dengan penyelenggaraan pendidikan agama Islam di kelas, khususnya pada bidang studi Akidah Akhlak sebagai unsur

\footnotetext{
${ }^{5}$ Slameto, Belajar dan Faktor-faktor yang Mempengaruhinya, (Jakarta: Rineka Cipta, 2003), 1

${ }^{6}$ Muhaimin, Paradigma Pendidikan Islam, (Bandung: Remaja Rosda Karya, 2002), 190

${ }^{7}$ Ibid., 196

${ }^{8}$ Djamarah, Syaiful Bahri.Psikologi Belajar, (Jakarta: Rineka Cipta, 2002), 38

${ }^{9}$ Budiningsih, C Asri, Belajar dan Pembelajaran, (Jakarta: Rineka Cipta, 2005), 43
} 
utama dari pendidikan agama Islam. Pada bidang studi Akidah Akhlak siswa dihadapkan pada pembelajaran yang bertujuan agar peserta didik mampu membedakan antara yang baik dan buruk, serta agar peserta didik mampu melakukan perbuatan-perbuatan yang terpuji dalam kehidupan sehari-hari.

Dengan mengaplikasikan metode discovery learning dalam bidang studi Akidah Akhlak diharapkan berdampak positif dan membawa perubahan dalam kehidupan sehari-hari. Siswa dalam pembelajaran dihadapkan pada proses berfikir reflektif untuk meningkatkan motivasi belajar. Kemampuan siswa dalam memecahan masalah (Problem Solving) harus selalu diasah dalam proses pembelajaran, yaitu dengan menggunakan kegiatan belajar mengajar yang menempatkan siswa pada latihan menggunakan metode-metode memecahkan masalah.

Penggunaan metode pembelajaran pada bidang studi Akidah Akhlak di MTs Pondok Pesantren Salman Al-Farisi Karanganyar Solo yang masih menggunakan cara-cara pembelajaran tradisional beraviliasi pada teacher oriented dan bermodus Ekspository misalnya ceramah yang monoton dan statis, akontekstual, cenderung normatif, monolitik, lepas dari sejarah, dan semakin akademis. Hal ini berimbas pada motivasi belajar siswa, pembelajaran yang monoton dan tidak melibatkan siswa secara aktif dalam aktivitas belajar cenderung membuat siswa bermalasmalasan dan tidak menunjukkan sikap-sikap ketertarikan terhadap pelajaran yang disampaikan.

Apabila kondisi yang memprihatinkan tersebut tetap dibiarkan, maka dapat menyebabkan otak peserta didik menjadi tumpul dan rendah dalam kemampuan berfikir kritis. Dengan demikian aplikasi sebuah metode belajar menempati peranan yang tidak kalah pentingnya dari komponen lainnya dalam kegiatan belajar mengajar. ${ }^{10}$ Maka dari itu, pentingnya melibatkan anak didik secara aktif dalam kegiatan pembelajaran di kelas adalah untuk menumbuhkan motivasi dalam diri siswa untuk belajar. Jika siswa tampak tidak termotivasi untuk belajar dapat menjadi sebuah masalah yang penting dan perlu diperhatikan.

Dari keterangan tersebut menunjukkan bahwa faktor yang sangat mempengaruhi siswa dalam belajar adalah motivasi. Motivasi sangatlah diperlukan, sebab seseorang yang tidak mempunyai motivasi dalam belajar, tak akan mungkin

${ }^{10}$ Djamarah, Syaiful Bahri \& Aswan Zain, Strategi Belajar Mengajar, (Jakarta: Rineka Cipta, 2002), 83 
melakukan aktivitas belajar. Kondisi tersebut harus segera dirubah dengan mencari dan mengaplikasikan metode belajar yang lain sebagai alat motivasi. Kuat lemahnya motivasi belajar seseorang turut mempengaruhi keberhasilan belajar. Dengan demikian, usaha meningkatkan motivasi belajar adalah sangat perlu dan penting, terutama motivasi yang berasal dari dalam diri siswa (motivasi intrinsik) dengan cara senantiasa memikirkan masa depan yang penuh tantangan dan harus dihadapi untuk mencapai cita-cita. Senantiasa memasang tekad bulat dan selalu optimis bahwa cita-cita dapat dicapai dengan belajar.

Aplikasi metode Discovery Learning lebih melibatkan siswa dalam kegiatan belajar yang aktif siswa diharapkan mempunyai motivasi belajar yang lebih tinggi dan terus meningkat. Siswa diharapkan dapat belajar dengan lebih mandiri, berfikir kritis dan kreatif dalam memecahkan berbagai permasalahan yang diberikan. Dengan munculnya motivasi intrinsik siswa merasa bangga menumbuhkan percaya diri karena dapat memecahkan masalah dengan baik, siswa akan lebih senang dan akan memberikan dorongan untuk selalu mengingat materi pelajaran yang telah disampaikan.

Belajar merupakan suatu mental proses yang aktif. Hal ini dapat dipahami pada proses pemecahan masalah siswa selalu melibatkan motivasi belajar yang tinggi. Dengan melihat persoalan tersebut, perlulah menerapkan suatu metode pembelajaran yang dapat memfasilitasi siswa untuk berperan aktif dalam pembelajaran. Selain metode tersebut harus memfasilitasi siswa untuk mengasah otak berfikir kritis, sistematis sehingga siswa dapat menguasai suatu keterampilan proses pemecahan masalah secara kreatif, sekaligus dengan metode yang digunakan dapat memotivasi belajar siswa. Dengan munculnya motivasi belajar, siswa akan lebih senang dalam mengingat-ingat materi pelajaran yang telah disampaikan dan metode discovery learning merupakan pilihan yang tepat.

Bertolak dari masalah-masalah yang dihadapi di dunia pendidikan khususnya di kelas-kelas. Pada pendidikan formal, guru adalah praktisi yang paling bertanggung jawab atas berhasil tidaknya program pembelajaran di kelas-kelas pada sekolah. Hal ini disebabkan karena seorang guru merupakan ujung tombak atau memilki peran yang penting dalam kegiatan pembelajaran di ruang kelas. Guru turut menentukan kualitas pendidikan, bahwa kunci utama peningkatan kualitas pendidikan ialah mutu para gurunya. Dengan demikian tugas guru harus selalu melakukan inovasi dengan memperbaiki dan atau meningkatkan kualitas praktek- 
praktek pembelajaran dengan melakukan suatu tindakan-tindakan kongkrit dalam pembelajaran di kelas sesuai dengan karakteristik pelajaran secara professional.

Dengan memperhatikan permasalahan tentang peningkatan kualitas pembelajaran dan berbagai masalah yang dihadapi dalam proses pembelajaran harus melakukan perencanaan dalam rangka menjawab tantangan tersebut. Suatu bentuk perencanaan pembelajaran merupakan hal yang penting karena sebuah kegiatan pembelajaran yang diawali dengan melakukan kegiatan penyusunan perencanaan akan meningkatkan kualitas pembelajaran dan meningkatkan hasil belajar.

Untuk mengakomodir hal tersebut, Guru perlu melakukan perbaikanperbaikan (inovasi) dengan tindakan-tindakan yang efektif, menerapkan berbagai metode pembelajaran, menerapkan strategi mengajar tertentu yang secara teoritis dapat dipertanggungjawabkan dan melakukan pemantauan terhadap hasil pembelajaran.

Aplikasi metode Discovery Learning dalam pembelajaran berdasarkan beberapa pertimbangan, yaitu: dalam aplikasi metode Discovery Learning pemberdayaan potensi siswa dapat lebih ditingkatkan apabila dalam siswa dilibatkan secara aktif dalam proses belajar di kelas sebagaimana pendapat Piaget, bahwa: anak harus berperan aktif dalam belajar di kelas. Dalam mengaktifkan siswa di kelas cara belajar yang baik menurut Jerume S. Bruner adalah memahami konsep, arti, dan hubungan, melalui proses intuitif untuk akhirnya sampai kepada suatu kesimpulan (Discovery Learning).

Dengan Discovery learning siswa ditempatkan pada lingkungan yang dikondisikan dalam bentuk desain pembelajaran yang eksploratif, di mana siswa berperan secara aktif dalam belajar di kelas dengan melakukan eksplorasi bahan pelajaran. Siswa dihadapkan pada lingkungan belajar yang mendorongnya untuk melakukan aktivitas menemukan sesuatu sebagai suatu aktivitas belajar yang lebih berarti dan bermakna. Sesuai dengan karakteristik mata pelajaran Al-Quran Hadis yang membutuhkan kemampuan untuk mengeksplorasi nilai-nilai ajaran Islam dalam bahan pelajaran secara intens yang kemudian dapat diterapkan dan dilaksanakan secara relevan dalam kehidupan sehari-hari.

Dengan kondisi yang tercipta dalam aplikasi metode Discovery Learning siswa belajar dengan lebih menyenangkan dihantarkan untuk kreatif menemukan suatu konsep dalam pelajaran, hal ini memungkinkan siswa lebih termotivasi dari dalam diri untuk belajar, dan apabila makin sering digunakan metode Discovery 
Learning dalam belajar memungkinkan siswa menguasai keterampilan dalam pemecahan masalah. Berdasarkan pendapat para ahli psikologi di atas, dapat disimpulkan bahwa dengan aplikasi Discovery Learning dapat meningkatkan motivasi belajar siswa.

Adapun alasan peneliti memilih MTs Pondok Pesantren Salman Al-Farisi Karanganyar Solo sebagai obyek penelitian karena berdasarkan hasil observasi awal menunjukkan bahwa kegiatan belajar dan mengajar pada bidang studi Akidah Akhlak di MTs Pondok Pesantren Salman Al-Farisi Karanganyar Solo masih didominasi dengan menerapkan metode belajar yang teacher oriented dan bermodus ekspository dengan menyampaikan materi belajar secara menyeluruh atau ceramah. Dengan penggunaan metode ceramah ini siswa nampak tidak dapat berpikir kritis untuk memecahkan masalah, selama kegiatan belajar mengajar siswa tidak menunjukkan antusias/motivasi belajar yang tinggi, disamping itu motivasi untuk mengingat pelajaran yang telah diterima juga cenderung rendah yang menyebabkan siswa enggan mengulang materi pelajaran.

Selain itu berdasarkan hasil penelitian sementara,kemampuan memecahkan masalah siswa masih cenderung rendah, selain itu motivasi belajar siswa masih rendah, hal ini nampak pada kegiatan belajar yang dipantau kepala sekolah siswa terlihat pasif untuk berinteraksi dalam kegiatan belajar mengajar. Hal itu di kuatkan juga oleh guru bidang studi Akidah Akhlak yang menyebutkan bahwa dorongan siswa untuk mengerjakan tugas-tugas di kelas sangat rendah, hal tersebut menurut guru bidang studi disebabkan kurang adanya motivasi belajar siswa dalam menerima pelajaran yang kurang maksimal. Selain itu nilai rata-rata pre-tes yang diperoleh pada pertemuan penjajakan, pada motivasi belajar siswa nilai rata-rata pre tes sebesar 1.3. Oleh karena itu peningkatan motivasi belajar siswa pada bidang studi Akidah Akhlak sangat perlu ditingkatkan.

Berdasar pada permasalahan tersebut, melatar belakangi penulis untuk meneliti tentang penerapan metode Discovery Learning untuk meningkatkan motivasi belajar pada sebuah lembaga pendidikan bercirikan Islam yaitu MTs Pondok Pesantren Salman Al-Farisi Karanganyar Solo. 


\section{Metode Penelitian}

Penulis menggunakan jenis penelitian yang bersifat kuantitatif asosiatif, sebab dalam penelitian ini penulis ingin menggali lebih jauh tingkat keefektivitasan Aplikasi Metode Discovery Learning Dalam Meningkatkan Motivasi Belajar Siswa Di MTs Pondok Pesantren Salman Al-Farisi Karanganyar Solo. Maka untuk mendeskripsikannya, digunakan beberapa rumus statistik, sehingga penelitian ini dikenal dengan penelitian kuantitatif. Dalam penelitian ini, penulis menggunakan penelitian kuantitatif di mana proses penggalian informasi diwujudkan dalam bentuk angka-angka sebagai alat untuk menemukan keterangan mengenai apa yang diketahui. $^{11}$

Dalam pengumpulan data, penulis menggunakan tehnik pengumpulan data berupa observasi, interview (wawancara), dokumentasi, dan angket. Untuk mengetahui pelaksanaan metode Discovery Learning dan motivasi belajar siswa penulis menggunakan rumus prosentase, sedangkan untuk mengetahui ada tidaknya pengaruh metode Discovery Learning terhadap motivasi belajar siswa penulis menggunakan rumus product moment ( $r x y)$.

\section{Hasil Penelitian dan Pembahasan}

\section{Definisi Metode Discovery Learning}

Metode pembelajaran Discovery Learning (Penemuan) adalah metode mengajar yang mengatur pengajaran sedemikian rupa sehingga anak memperoleh pengetahuan yang sebelumnya belum di ketahuinya. Dalam pembelajaran discovery (penemuan) kegiatan atau pembelajaran yang di rancang sedemikian rupa sehingga siswa dapat menemukan konsep- konsep dan prinsip-prinsip melalui proses mentalnya sendiri. Pembelajaran dengan discovery learning (penemuan) merupakan suatu komponen penting dalam pendekatan kontruktivis yang telah memiliki sejarah panjang dalam dunia pendidikan. ${ }^{12}$ Metode secara harfiah berarti "cara". Dalam pemakaian yang umum, metode diartikan sebagai cara melakukan sesuatu kegiatan atau cara melakukan pekerjaan dengan menggunakan fakta dan konsep-konsep secara sistematis. ${ }^{13}$

Sedangkan menurut Tafsir memberikan pengertian bahwa: metode ialah istilah

\footnotetext{
${ }^{11}$ Margono, Metodologi Penelitian Pendidikan, (Jakarta: Rineke Cipta, 1997), 105

${ }^{12}$ Suprihatiningrum, Jamil, Strategi Pembelajaran (Jogjakarta: Ar Ruzz Media, 2013), 241

${ }^{13}$ Syah, Muhibbin, Psikologi Pendidikan dengan Pendekatan Baru, (Bandung: Remaja Rosda Karya, 2004), 201
} 
yang digunakan untuk mengungkapkan pengertian "cara yang paling tepat dan cepat dalam melakukan sesuatu". Lebih lanjut Tafsir menjelaskan bahwa: ungkapan "paling tepat dan cepat" itulah yang membedakan method dengan way (yang berarti cara) dalam bahasa Inggris.

Selain pengertian tersebut, metode bukan hanya sebatas cara melakukan sesuatu akan tetapi metode diartikan sebagai cara untuk mencapai sesuatu sebagaimana pendapat Gulo ${ }^{14}$ yang menjelaskan bahwa: metode ialah " $a$ way in achieving some thing" cara untuk mencapai sesuatu. Metode Discovery Learning sebagai sebuah teori belajar dapat didefinisikan sebagai belajar yang terjadi bila pelajar tidak disajikan dengan pelajaran dalam bentuk finalnya, tetapi diharapkan untuk mengorganisasi sendiri. Sebagaimana pendapat Bruner, bahwa: "Discovery Learning can be defined as the learning that takes place when the student is not presented with subject matter in the final form, but rather is required to organize it him self" (Lefancois dalam Emetembun, Yang menjadikan dasar ide Bruner ialah pendapat dari Piaget yang menyatakan bahwa anak harus berperan secara aktif didalam belajar di kelas. Untuk itu Bruner memakai metode yang disebutnya Discovery Learning, yaitu dimana murid mengorganisasi bahan yang dipelajari dengan suatu bentuk akhir. ${ }^{15}$

Metode Discovery Learning adalah memahami konsep, arti, dan hubungan, melalui proses intuitif untuk akhirnya sampai kepada suatu kesimpulan. ${ }^{16}$ Discovery terjadi bila indifidu terlibat, terutama dalam penggunaan proses mentalnya untuk menemukan beberapa konsep dan prinsip. Discovery dilakukan melalaui proses mental, yakni, observasi, klasifikasi, pengukuran, prediksi, penentuan dan inferi. Lebih lanjut, sebagai sebuah strategi belajar Discovery Learning mempunyai prinsip yang sama dengan inkuiri (inquiry) dan Problem Solving. Tidak ada perbedaan yang prinsipil pada ketiga istilah ini, pada Discovery Learning lebih menekankan pada ditemukannya konsep atau prinsip yang sebelumnya tidak diketahui. Mempunyai prinsip yang sama dengan inquiry, yang menuntut usaha menemukan seperti itu.

Akan tetapi prinsip belajar yang nampak jelas dalam Discovery Learning adalah materi atau bahan pelajaran yang akan disampaikan tidak disampaikan dalam bentuk final akan tetapi siswa sebagai peserta didik didorong untuk mengidentifikasi

\footnotetext{
${ }^{14}$ Gulo, W. Strategi Belajar Mengajar (Jakarta: Grasindo, 2002), 3

${ }^{15}$ Dalyono, M. Psikologi Pendidikan, (Semarang: Rineka Cipta, 1996), 41.

${ }^{16}$ Budiningsih, C Asri. Belajar dan Pembelajaran, (Jakarta: Rineka Cipta, 2005), 43
} 
apa yang ingin diketahui dilanjutkan dengan mencari informasi sendiri kemudian mengorgansasi atau membentuk (konstruktif) apa yang mereka ketahui dan mereka pahami dalam suatu bentuk akhir. Sebagaimana pemikiran Bruner bahwa: perolehan pengetahuan adalah proses aktif. Individu secara aktif merekontruksi pengalamannya dengan menghubungkan pengetahuan baru dengan internal modal atau struktur kognitif yang telah dimilikinya.

Dengan demikian dalam mengaplikasikan metode Discovery Learning dalam sebuah bahan ajar pada suatu bidang studi tertentu maka tidak semua materi pelajaran yang harus dipelajari siswa dipresentasikan dalam bentuk final, beberapa bagian harus dicari diidentifikasikan oleh pelajar sendiri. Pelajar mencari informasi sendiri. ${ }^{17}$ Sebagaimana pendapat Ausubel, bahwa dalam metode Discovery Learning si pelajar menemukan sendiri materi yang harus dipelajarinya. Ia tidak hanya menyerap saja, tetapi mangorganisir dan mengintegrasikan materi-materi yang dipelajarinya ke dalam struktur kognitifnya. Sehingga dengan mengaplikasikan metode Discovery Learning secara berulang-ulang dapat meningkatkan kemampuan penemuan dari individu yang bersangkutan. ${ }^{18}$ Penggunaan metode Discovery Learning, ingin merubah kondisi belajar yang pasif menjadi aktif dan kreatif. Mengubah pembelajaran yang teacher oriented ke student oriented. Merubah modus Ekspository siswa hanya menerima informasi secara keseluruhan dari guru ke modus Discovery siswa menemukan informasi sendiri.

\section{Lingkungan Belajar dalam Metode Discovery Learning}

Di dalam proses belajar, Bruner mementingkan partisipasi aktif dari tiap siswa, dan mengenal dengan baik adanya perbedaan kemampuan. Untuk menunjang proses belajar perlu lingkungan memfasilitasi rasa ingin tahu siswa pada tahap eksplorasi. Lingkungan ini dinamakan Discovery Learning Environment, ialah lingkungan dimana siswa dapat melakukan eksplorasi, penemuan-penemuan baru yang belum dikenal atau pengertian yang mirip dengan yang sudah diketahui. ${ }^{19}$ Lingkungan seperti ini bertujuan agar siswa dalam proses belajar dapat berjalan dengan baik dan lebih kreatif. Untuk memfasilitasi proses belajar yang baik dan kreatif harus berdasarkan pada manipulasi bahan pelajaran sesuai dengan tingkat

\footnotetext{
${ }^{17}$ Slameto, Belajar dan Faktor-faktor yang Mempengaruhinya (Jakarta: Rineka Cipta, 2003), 24

${ }^{18}$ Sarwono, Sarlito Wirawan, Teori-Teori Psikologi Sosial (Jakarta: Rajawali Pers, 2003), 92

${ }^{19}$ Slameto, Belajar dan Faktor-faktor yang Mempengaruhinya, (Jakarta: Rineka Cipta, 2003), 140
} 
berkembangan kognitif siswa.

Manipulasi bahan pelajaran bertujuan untuk memfasilitasi kemampuan siswa dalam berfikir (merepresentasikan apa yang dipahami) sesuai dengan tingkat perkembangannya. Menurut Bruner perkembangan kognitif seseorang terjadi melalui tiga tahap yang ditentukan oleh caranya melihat lebih tepatnya menggambarkan lingkungan, yaitu: enactive, iconic, dan symbolic. ${ }^{20}$

a. Tahap enaktive, seseorang melakukan aktivitas-aktivitas dalam upaya untuk memahami lingkungan sekitarnya. Artinya, dalam memahami dunia sekitarnya anak menggunakan pengetahuan motorik. Misalnya melalui gigitan, sentuhan, pegangan, dan sebagainya.

b. Tahap iconic, seseorang memahami objek-objek atau dunianya melalui gambargambar dan visualisasi verbal. Maksudnya, dalam memahami dunia sekitarnya anak belajar melalui bentuk perumpamaan (tampil) dan perbandingan (komparasi).

c. Tahap symbolic, seseorang telah mampu memiliki ide-ide atau gagasan-gagasan abstrak yang sangat dipengaruhi oleh kemampuannya dalam berbahasa dan logika. Dalam memahami dunia sekitarnya anak belajar melalui simbol-simbol bahasa, logika, matematika, dan sebagainya. Komunikasinya dilakukan dengan menggunakan banyak simbol. Semakin matang seseorang dalam proses berpikirnya, semakin dominan sistem simbolnya. Meskipun begitu tidak berarti ia tidak menggunakan sistem enaktif dan ikonik. Penggunaan media dalam kegiatan pembelajaran merupakan salah satu bukti masih diperlukannya sistem enaktif dan ikonik dalam proses belajar.

Secara sederhana teori perkembangan dalam fase enactive, iconic dan symbolic adalah anak menjelaskan sesuatu melalui perbuatan (ia bergeser ke depan atau kebelakang di papan mainan untuk menyesuaikan beratnya dengan berat temannya bermain) ini fase enactive. Kemudian pada fase iconic ia menjelaskan keseimbangan pada gambar atau bagan dan akhirnya ia menggunakan bahasa untuk menjelaskan prinsip keseimbangan ini fase symbolic.

${ }^{20}$ Budiningsih, C Asri, Belajar dan Pembelajaran, (Jakarta: Rineka Cipta, 2005), 41-4227 


\section{Aplikasi Metode Discovery Learning dalam Meningkatkan Motivasi Belajar}

Siswa di MTs Pondok Pesantren Salman Al-Farisi Karanganyar Solo

Aplikasi metode discovery learning di MTs Pondok Pesantren Salman AlFarisi Karanganyar Solo adalah sebagai berikut: identifikasi kebutuhan siswa, seleksi pendahuluan terhadap prinsip-prinsip pengertian konsep dan generalisasi pengetahuan, Seleksi bahan, problema/tugas-tugas, membantu dan memperjelas tugas atau problema yang di hadapi siswa serta peranan masing-masing siswa, mempersiapkan kelasa dan alat-alat yang di perlukan, mengecek pemahan siswa terhadap masalah yang akan di pecahkan, memberi kesempatan pada siswa untuk melakukan penemuan, membantu siswa dengan informasi atau data jika di perlukan oleh siswa, memimpin analisis sendiri dengan pertanyaan yang mengarahkan dan mengidentifikasi masalah, merangsang terjadinya interaksi antara siswa dengan siswa.

Berdasarkan analisa data tentang aplikasi metode Discovery Learning yang diterapkan di MTs Pondok Pesantren Salman Al-Farisi Karanganyar Solo tergolong kurang baik karena hasilnya $46 \%$ yang berada di antara $40-55 \%$. Keadaan metode Discovery Learning di MTs Pondok Pesantren Salman Al-Farisi Karanganyar Solo ternyata belum berjalan maksimal. Terbukti aktifitas siswa di sekolah motivasi belajarnya masih sangat lemah. Pernyataan ini di dukung dengan hasil penelitian yang menunjukkan bahwa hasil Jika dilihat pada standart prosentase, maka terdapat pada skala 40 - 55\% yaitu tergolong pada criteria kurang baik. Mengenai motivasi belajar siswa di MTs Pondok Pesantren Salman Al-Farisi Karanganyar Solo dapat di simpulkan dalam kriteria kurang baik. Hal ini dibuktikan dengan minat belajar siswa yang baik dan dari hasil prosentase tentang motivasi belajar siswa pada prosentase $40-55 \%$ dengan prosentase $41 \%$ yaitu tergolong pada kategori kurang baik.

Pengaruh aplikasi metode Discovery Learning dalam meningkatkan motivasi belajar siswa di MTs Pondok Pesantren Salman Al-Farisi Karanganyar Solo dapat dikatakan tidak berpengaruh. Hal ini berdasarkan analisis data dengan rumus " $\mathrm{r}$ " product moment rxy sebesar 0.077 dan untuk mengetahui sejauh mana pengaruh aplikasi metode discovery learning dalam meningkatkan motivasi belajar siswa di MTs Pondok Pesantren Salman Al-Farisi Karanganyar Solo dapat di interpretasikan pada tabel " $r$ " product moment. Interpretasi $r=0.077$ menunjukkan rentang antara $0.00-0.20$ yang berarti antara variabel $\mathrm{x}$ dan variabel $\mathrm{y}$ memiliki korelasi yang sangat lemah dan sangat rendah (dianggap tidak ada korelasi). Pada pengujian 
hipotesis (N) 25 yang kemudian di cocokkan dengan taraf signifikansi 5\% didapatkan angka 0.396 dan taraf signifikansi 1\% didapatkan angka 0.505.

Menunjukkan bahwa Hipotesa Kerja (Ha) ditolak, yaitu tidak ada pengaruh aplikasi metode Discovery Learning dalam meningkatkan motivasi belajar siswa di MTs Pondok Pesantren Salman Al-Farisi Karanganyar Solo. Aplikasi metode ini pengaruhnya sangat lemah terhadap peningkatan belajar siswa di MTs Pondok Pesantren Salman Al-Farisi Karanganyar Solo di karenakan faktor-faktor sebagai berikut:

a. Metode Discovery Learning baru di terapkan di sekolah ini.

b. Lemahnya respon siswa terhadap metode baru yang di terapkan.

c. IQ siswa yang berbeda.

d. Interaksi antara guru dan siswa kurang maksimal.

\section{Kesimpulan}

Penelitian ini dapat di simpulkan bahwa aplikasi metode discovery learning di MTs Pondok Pesantren Salman Al-Farisi Karanganyar Solo adalah sebagai berikut: identifikasi kebutuhan siswa, seleksi pendahuluan terhadap prinsip-prinsip pengertian konsep dan generalisasi pengetahuan, Seleksi bahan, problema/tugastugas, membantu dan memperjelas tugas atau problema yang di hadapi siswa serta peranan masing-masing siswa, mempersiapkan kelasa dan alat-alat yang di perlukan, mengecek pemahan siswa terhadap masalah yang akan di pecahkan, memberi kesempatan pada siswa untuk melakukan penemuan, membantu siswa dengan informasi atau data jika di perlukan oleh siswa, memimpin analisis sendiri dengan pertanyaan yang mengarahkan dan mengidentifikasi masalah, merangsang terjadinya interaksi antara siswa dengan siswa. Dan hasil penelitian ini menunjukkan bahwa tidak ada pengaruh aplikasi metode Discovery Learning terhadap motivasi belajar siswa dengan skor 0.077. Jika dilihat pada tabel interpretasi nilai "r" product moment berada pada rentang $0.00-0.20$ yang berarti antara variabel $\mathrm{x}$ dan varibel y terdapat korelasi yang sangat lemah atau sangat rendah (dianggap tidak ada korelasi di antara keduanya). 


\section{Referensi}

Asri, Budiningsih, C (2005), Belajar dan Pembelajaran, Jakarta: Rineka Cipta.

Dalyono, M. (1996), Psikologi Pendidikan, Semarang: Rineka Cipta.

Gulo, W. (2002), Strategi Belajar Mengajar, Jakarta: Grasindo.

Margono (1997), Metodologi Penelitian Pendidikan, Jakarta: Rineke Cipta.

Muhaimin (2002), Paradigma Pendidikan Islam, Bandung: Remaja Rosda Karya.

Nurhadi, dkk (2004), Pembelajaran Kontekstual dan Penerapannya dalam KBK, Malang: Universitas Negeri Malang.

Sarwono, Sarlito Wirawan (2003), Teori-Teori Psikologi Sosial, Jakarta: Rajawali Pers.

Slameto (2003), Belajar dan Faktor-faktor yang Mempengaruhinya, Jakarta: Rineka Cipta.

Suprihatiningrum, Jamil (2013), Strategi Pembelajaran, Jogjakarta: Ar Ruzz Media.

Syah, Muhibbin (2004), Psikologi Pendidikan Dengan Pendekatan Baru, Bandung: Remaja Rosda Karya.

Syaiful Bahri, Djamarah, \& Aswan Zain (2002), Strategi Belajar Mengajar, Jakarta: Rineka Cipta. 